\title{
Revisión | Review \\ Secondary metabolites as a survival strategy in plants of high mountain habitats
}

[Metabolitos secundarios como estrategia de supervivencia en plantas de hábitat de alta montaña]

\author{
Diego Rodríguez-Hernández ${ }^{1,2}$ \\ ${ }^{1}$ Grupo de Química Ecológica, Facultad de Ciencias, Universidad de Los Andes, 5106 Mérida, Venezuela \\ ${ }^{2}$ Current address: Faculdade de Ciências Farmacêuticas de Ribeirão Preto, Universidade de São Paulo (FCFRP-USP), Brazil \\ Contactos | Contacts: Diego RODRÍGUEZ-HERNÁNDEZ - E-mail address: dcrh86@usp.br
}

\begin{abstract}
This review work focuses on how the secondary chemistry could help in the survival of plants in high mountain habitats under extreme environmental conditions. The elevated levels of stress in high areas of the tropic and subtropic change dramatically not only by following the annual cycles of winter and summer but they also change in a single day. Some species, however, are able to successfully grow at heights more than $3000 \mathrm{~m}$ in the tropical mountains due, in part, to highly specialized physiological processes that affect their physical and chemical responses. In this study, it describes some strategies of how the secondary metabolites could help the plants to stand the high levels of stress in the high mountain ecosystems.
\end{abstract}

Keywords: Abiotic stress; Biotic stress; Secondary metabolites; Environments of high altitude.

\begin{abstract}
Resumen: Este trabajo de revisión se centra en cómo la química secundaria podría ayudar en la supervivencia de plantas en hábitats de alta montaña en condiciones ambientales extremas. Los altos niveles de estrés en las zonas altas del trópico y subtrópico cambian dramáticamente no solo al seguir los ciclos anuales de invierno y verano, sino que también cambian en un solo día. Sin embargo, algunas especies pueden crecer con éxito a alturas superiores a $3000 \mathrm{~m}$ en las montañas tropicales debido, en parte, a procesos fisiológicos altamente especializados que afectan sus respuestas físicas y químicas. En esta revisión, se describen algunas estrategias de cómo los metabolitos secundarios podrían ayudan a las plantas a soportar los altos niveles de estrés en los ecosistemas de alta montaña.
\end{abstract}

Palabras clave: Estrés abiótico; Estrés biótico; Metabolitos secundarios; Ambientes de gran altura.

Recibido | Received: February 5, 2019

Aceptado | Accepted: June 13, 2019

Aceptado en versión corregida | Accepted in revised form: July 14, 2019

Publicado en línea | Published online: September 30, 2019

Este artículo puede ser citado como / This article must be cited as: D Rodríguez-Hernández. 2019 Secondary metabolites as a survival strategy in plants of high mountain habitats. Bol Latinoam Caribe Plant Med Aromat 18 (5): 444 - 458.

Https://doi.org/10.35588/blacpma.19.18.5.29 


\section{INTRODUCTION}

A characteristic of most terrestrial plants is their sedentary nature, although some plant species develop vegetative in different directions from their anchoring place, remaining in the same place. This sedentary nature has a profound impact on the life history of individuals, as well as on the structure of the biome community associated with them. The germination, the settlement of the seedlings, their growth, their reproduction, and their propagation are determinants for the environmental characteristics, both in the physical aspect and in the biotic.

Plants that grow at high altitude levels grow in extremely fragile ecosystems, usually as endemic species of short stature with some exceptional tree biological types such as the case of the genus Polylepis, whose growth is generally low. The plants are exposed to environmental conditions that change with altitude and latitude. In the high mountain (above 3500 m.a.s.1.), exist isolated or desert territories, this has led to the plants being affected by inbreeding and genetic drift (Ma et al., 2015). Therefore, it is foreseen that species whose ecological territories are placed in altitudinal gradients of considerable amplitude have a complex genetic structure and a combination of adaptive and plastic responses to the changing conditions of the environment (Oleksyn et al., 1998). Knowing the type of response, genetic versus plastic, allows to elucidate if the different phenotypes correspond to genotypes considered as result of the differential pressures of selection or, if the ecological responses are a result of the plasticity of the species, expressing different phenotypes in response to contrasting conditions of the altitudinal gradient (Premoli \& Mathiasen, 2011).

To understand the responses of plants at high elevations, it is crucial to understand the differences between adaptation and acclimation. Acclimation, also known as phenotypic adaptation, could be presented as genetic progress that takes place on an evolutionary timescale, controlled by gradual modification of the genome in combination with the pressure of the environment that leads to natural selection according to the Darwinian model. Otherwise, adaptation is a phenomenon that occurs in ecological time, within the life cycle of an individual, therefore, much shorter and that depends on the capacity of intrinsic response of the species to the new climates in accordance with its ability to colonize new territories, this phenomenon is also known as genotypic adaptation.

To distinguish the adaptability of high mountain plant species, the study of a series of characteristics related to the aptitude of the plant and the altitudinal adaptation is required. In general, it is recognized that phenotypic variation along altitudinal gradients are due to more difficult conditions with height gain (Körner, 2007). The higher the altitude, the smaller the plants, reduce the reproductive investment and increase the investment in energy to form denser layers of tissue on the leaf, helping in structural defense storage (Körner, 1989). The diversity of the secondary chemistry also plays an important role in the adaptation and acclimatization of plants to these high habitats, different types of secondary metabolites according to their structure could participate in the mediation of these parameters and some of them are analyzed in this review.

\section{Stress factors on high environments}

The different biotic and abiotic gradients that affect animal and plant life in an integrated manner are not well defined due to their complexity. The most observed components in an altitude gradient are shown in Figure No. 1.

The strong climatic and edaphic conditions affect the living environment. The severe stress conditions present in high elevation habitat negatively affect the growth and development of plants. Understanding the mechanisms through which plants transmit signals to the cellular machinery to activate adaptive responses is very important. Signal transduction pathways are the link between the detection mechanism and the genetic response. Plants face environmental changes by activating signal transduction cascades that control and coordinate the physiological and biochemical responses necessary for adaptation (Huang et al., 2012).

The regulation of gene expression, as part of stress responses, involves changes in the transcription levels of some plant genes (Shinozaki \& YamaguchiShinozaki, 2000). According to the presence of these mechanisms of tolerance to general and specific abiotic stress, plants are expected to have multiple ways of perceiving stress and, in response, transduction signals that can mitigate this effect (Chinnusamy et al., 2004).

The adaptability of high elevation plants could depend on different factors, among them we have: (i) genetic adaptation between populations with the flow of genes along the altitudinal gradient in the 
long term. (ii) the phenotypic plasticity of the characteristics in the short-term selection and (iii) the variation of the gradient between the genetic and environmental influences in these characteristics (Gonzalo-Turpin \& Hazard, 2009). In total, the number of plant species adapted to live at high elevations decreases as the percentage of specialized endemism increases, especially in isolated mountain ranges (Vetaas \& Grytnes, 2002; Giménez et al., 2004).

\section{Stress factors in high mountain habitats

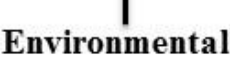 \\ conditions}

Biotic factors

- Vegetal composition

- Competition between plants

- Herbivory

- Acclimation and Adaptation

- Genotype and Phenotype

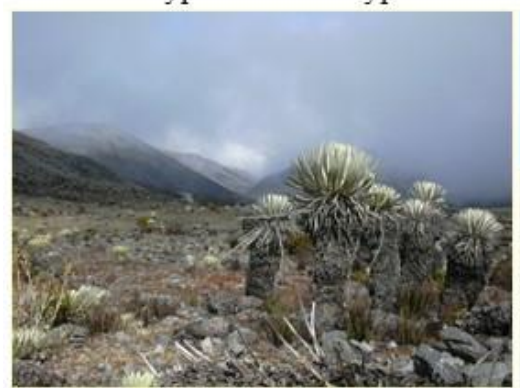

Figure No. 1
Abiotic factors

- Air and soil temperatura

- Soil mineralization

- Solar radiation

- Air humidity and Water regime

- Composition of atmospheric air

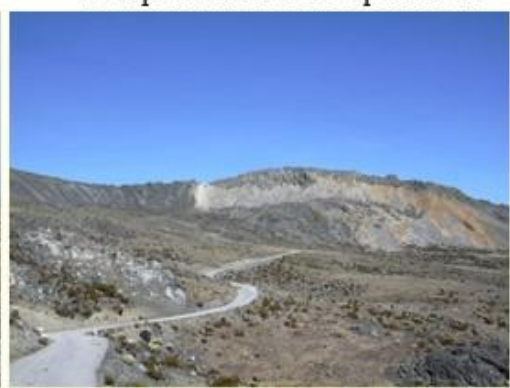

Most relevant altitudinal components. Andean páramos Mérida, Venezuela

An overall perspective of the altitudinal variation of secondary metabolites

Some patterns of secondary metabolites have been established in the vegetation according to the elevation of their habitat, as shown in Figure 2. The biosynthesis of different types of secondary metabolites is influenced by the environmental factors present in these ecosystems. In high altitude plants, environmental factors present drastic changes, generating variations in their secondary chemistry.

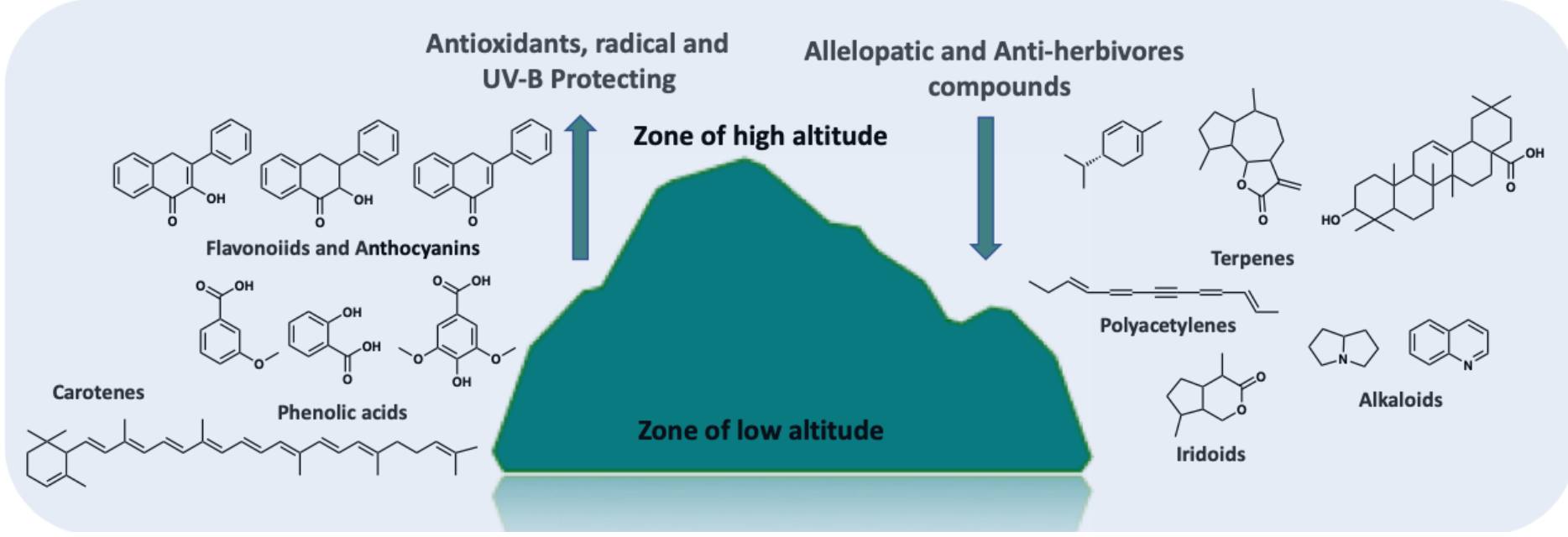

Figure No. 2

Altitudinal tendencies for different types of secondary metabolites of plants that shown different ecological functions (Zidorn, 2010) 
Below is a brief description of how these factors influence the presence of certain secondary metabolites in plants located at high elevations.

3.1. Biotic conditions as determinant:

If climate is an important factor, the selective pressure for herbivore is less pronounced. The climatic factors reduce the reproduction capability of insects besides, the acclimation difficulties, accessibility or abundance of resources according to the altitudinal pattern, it will give as a result of a decrease of the anti-herbivore response from lowaltitude to high-altitude zones (Callis-Duehl et al., 2017; González-Reyes et al., 2017). For instance, a general decrease in plant palatability has been associated with a reduction in herbivore pressure at high elevation (Descombes et al., 2016). According to this criterion, high elevation plants that experience lower levels of herbivory are expected to have lower levels of defense against herbivores compared to their families at lower altitudes.

\section{Abiotic conditions as determinant}

Extreme climatic conditions are factors of abiotic stress in plants regarding radiation and temperature. While it is true that UV-B radiation may directly cause damages to DNA, the harmful effect of low temperature is indirect, both factors in plant cells produce reactive oxygen species (ROS) increased oxidative damage (Zlatev \& Lidon, 2012). Consequently, compounds that improve the impact of, for example, low temperatures, UV-B radiation or generation of reactive oxygen species would increase in high altitudes (Körner, 2003).

Both biotic and abiotic factors have been presented for experimental verification. First, the influence of biotic factors could be supported by different studies reported in the literature. For instance, Carey \& Wink (1994) showed a decrease in the content of total quinolizidine alkaloids in seeds and leaves of populations of Lupinus argenteus Pursh, a perennial herbaceous found in 7 places of high altitude (2776 - 3600 m.a.s.l.) in the western Rocky Mountains of North America. Although authors did not define the content of nitrogen $(\mathrm{N})$ in soil or in the leaf that could have influenced the accumulation rate of total alkaloids, it was observed that this difference in the content of alkaloids is at least partially heritable and therefore, genetically determined. It would be therefore the responsibility of the case of acclimation that is attributable to a constitutive response. However, other plants of high elevation like Lupinus meridanus and L. eremonomo that grow above $4000 \mathrm{~m}$ a.s.l. in the Venezuelan páramo accumulate big quantities of alkaloids, mainly sparteine and lupin (Rojas, 1998). Other species of the South American high páramo like Senecio formosus H.B.K accumulates $0.52 \%$ of pyrrolizidine alkaloids divided into 7 different compounds. These substances are highly hepatotoxic (Toro-Gonzales et al., 1997) even though the pressure of herbivores and phytopathogens is not important in the zone. Nevertheless, its relation with phenology or with environmental conditions is still unknown since there is no systematic studies as to confirm or deny the hypothesis of Carey and Wink (Alonso-Amelot, 2008). It has neither been analyzed from the perspective of the carbon/nitrogen $(\mathrm{C} / \mathrm{N})$ nutrient balance theory (Hamilton et al., 2001), despite it is known that $\mathrm{C} / \mathrm{N}$ rate in soil may directly influence the quantity and rate of secondary metabolites in plants (Ibrahim et al., 2011).

However, there are situations in which such a decrease in the population of herbivores is not verified, as in the case of abundant populations of herbivore Ortopthera, in the tropical Andean páramo above $3500 \mathrm{~m}$ a.s.l. (Calcagno-Pissarelli et al., 2010). Polylepis trees distributed along the Andean Mountains at $3000-5000 \mathrm{~m}$ a.s.1., lost about $20 \%$ of the total surface of the leaves in some locations in Colombia and Venezuela (Velez et al., 1998) where some Ortopthera species (e.g., Meridacris diabólica, Chibchacris carrikeri), and Coleopthera (Dyscolus $s p$ ), are potential specialists insects of Polylepis genus (Diaz et al., 1997). The chemical compounds isolated for this genus are mainly triterpenes oxygenated and flavonoids glycosidated (Catalano et al., 1995; Neto et al., 2000; Lozano et al., 2017), which indicates that its secondary chemistry could be oriented to other defense strategies. This suggests that the selective forces of abiotic conditions (e.g. cold hardiness) might be stronger than biotic conditions (e.g. resistance to herbivores) along elevation gradients, although this might be organ-specific, depending on the trait analyzed. Due to environmental pressure exposed at high elevations, the plants could lead to an increased protection (chemical and physics) of the highest value organs according to the optimal defense theory (Rasmann et al., 2014).

Second, the influence of abiotic factors could also be supported by different studies published in the literature. For example, the studies on Pteridium 
arachoideum (Kaulf.) Maxon and Pteridium caudatum (L.) Maxon ferns. revealed that both species contain high amounts of phenolic compounds with photoprotection and uptake of radicals in higher altitude sites than in lower areas (Alonso-Amelot et al., 2004; Alonso-Amelot et al., 2007). The tropical species of Pteridium have been shown to have a significant genetic plasticity that allows them to give an adaptive response in a wide range of elevations ranging from sea level up to 2900 m.a.s.l.

There is also a high content of flavones that efficiently filter part of the UV-B spectrum in páramo endemic species in which genetic plasticity does not seem to be important. A positive correlation between the phenolic and flavonoids compounds contents with rising altitude (4000-3200 m.a.s.l.) of plant habitats was proved for Hypericum orientale L. and $H$. pallens Banks \& Sol. (Camas et al., 2014). Rasmann et al., (2014) using information available in the literature, through meta-regression analysis, showed that leaf toughness in trees and flavonoids in reproductive organs of herbs increase with the elevation.

The decreased temperatures in higher altitudes have also been reported to have a distinct impact on the increase in phytochemical content of plants from higher altitudes. Picrorhiza kurroa Royle ex Benth., an endangered plant species of family Scrophulariaceae. This species is distributed between 3000-5000 m.a.s.l. in Himalaya, P. kurroa biosynthesize a class of natural products called picrosides, which are glycosides derivative with an iridane skeleton of monoterpene origin. A work reveled that picrosides levels in natural population of Picrorhiza kurroa, has been increased by $135 \%$ in the plants growing at high of 4145 m.a.s.l. as compared to plants that grown at low altitude (1350 m.a.s.l.) (Singh et al., 2005).

\section{Secondary chemistry of high-mountain plants: an approach of acclimation and adaptation}

Secondary chemistry is also a response to the acclimatization and adaptation of these high-altitude environments, which together with other responses, help plants overcome the types of stress present in these ecosystems. An outstanding case is present in Espeletiinaes subtribe rosettes, which is capable of biosynthesizing a variety of diterpenoids with a kaurane skeleton (Figure No. 3) and represents one of the main classes of natural products in plant species such as: Ruilopezia, Espeletiopsis, Espeletia,
Libanothamus and Coespeletia from the tropical Andes of Colombia and Venezuela (Usubillaga \& Morales, 1972; Padilla et al., 2017). Kaurenic acids such as: kaurenic acid (1), grandifloric acid (2) and grandiflorenic acid (3) were found in 72 species of this subtribe (Usubillaga et al., 2003; PadillaGonzález et al., 2017). Beside was reported an increase in the accumulation of kaur-16-ene (1) acid, from $0.83 \%$ (m / m) to $4.4 \%$ in leaves of Coespeletia timotensis, in samples taken in June and December at $4100 \mathrm{~m}$ a.s.l. in the tropical Andes. These environments - the minimum temperatures and precipitations decrease significantly (Rojas \& Usubillaga, 1998). The presence of these secondary metabolites could act as an adaptive response to low temperatures or drought in these Andean ecosystems.

The 19-carboxy-kaurene and its derivatives could give more flexibility to the lipid membranes of the plant, helping it to tolerate low temperatures as mentioned above. This assessment is confirmed by two works. First, Padilla-González et al. (2017), through studies of metabolomics, showed the presence of different types of kaurene (4-9, see Figure No. 3), these compounds were found in different concentrations in 72 different species of Espeletiinae subtribes collected at heights of over 3000 m.a.s.l. in the páramo of Colombia and Venezuela, between December of 2007 and August of 2011. In addition, an increase in the amount of kaur-16-in-19-al (10) was reported in five different species of Ruilopezia (giant rossettes), located in the high Andean north (Aparicio et al., 2001).

Allelopathy is a well-known strategy of competition between plants, and it is frequently regulated by the secondary metabolism by which plants interact in situations of competition due to lack of soil resources. The dynamics of allelopathic compounds in plant species that grow along the altitudinal gradient, where there could be an inclination of intra-plant competition, would undoubtedly be of great interest. To our knowledge, there is a lack of data on the systematic development of such information. However, Minthostachys mollis located in rough zones, rocky soils and without slopes drained in the Andean sub-páramo, has a slow growth in its natural environment. This species is used by farmers to preserve potato crops in a way that it prevents sprouts. Plants of "Muna" (name commonly used in Peru and Ecuador) are put inside potato bags. This helps to preserve the product for longer time. It undoubtedly presents an allelopathic 
effect. Alonso-Amelot et al. (2006) discovered that this species accumulates an unusual big quantity of (+) pulegone (13) (> 83\% of the essential oil, Figure No. 3) in exudates of glandular trichomes that have a strong inhibitory effect against seeds and weed plants potentially competitive. Labdane diterpene (14-17) and clerodane (18-20) (Figure No. 3) have been identified in the high páramo endemic species like Blakiella bartsiifolia and Oxylobus glanduliferus. These compounds show a strong inhibition against commercial plants (Amaro \& Adrian, 1982; Valero,
2010; Oliveros-Bastidas et al., 2011; RodriguezHernandez et al., 2014; Rodriguez-Hernandez et al., 2017). However, there is only the possibility of developing their allelopathic capacity in these habitats, since they proved to be soluble in hydrocarbons, but this would make their bioavailability much more difficult when transferred to the soil. It is unknown whether these or other compounds located in the exudates of the glandular trichomes have an adaptive role in mediation.<smiles>[R]C1C(=C)[C@H]2CC[C@H]3[C@]4(C)CCC[C@](C)(C(=O)O)[C@H]4CC[C@@]13C2</smiles>

$2 \mathrm{R}=\mathrm{OH}$
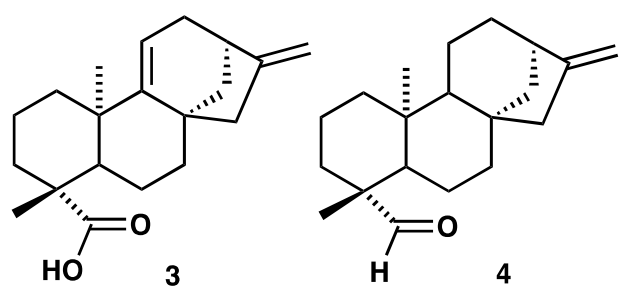

4
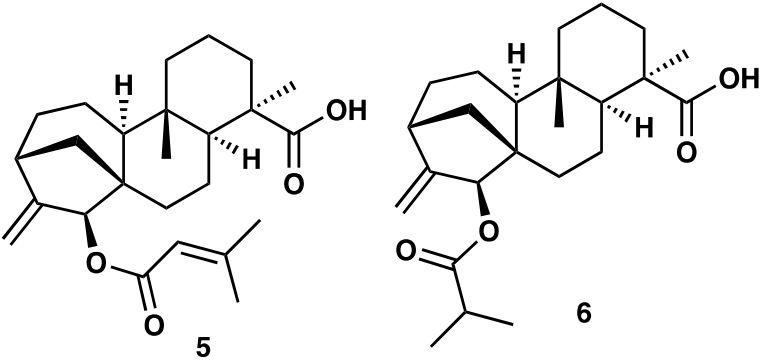

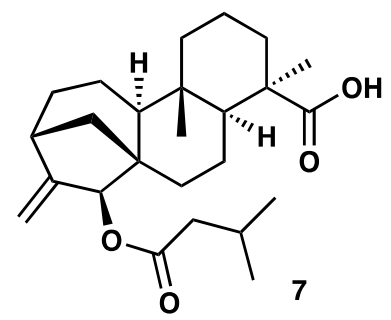

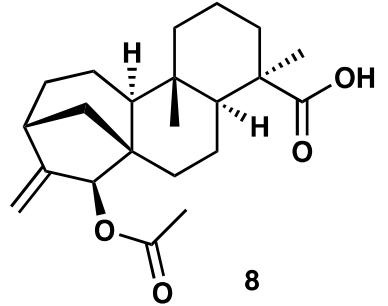<smiles>C=C1C[C@]23CC[C@H]4[C@@H](C(=O)O)CCC[C@]4(C)C2=C[C@@H](O)[C@@H]1C3</smiles>

9<smiles>C=C1C[C@]23CC[C@H]4[C@@](C)(C(=O)O)CCC[C@]4(C)C2=CC(=O)[C@H]1C3</smiles><smiles>CC(C)=C1CC[C@@H](C)CC1=O</smiles><smiles>[R]C(CCO)CC[C@@H]1[C@@](C)(O)CC[C@]2(C)C(C)(C)CCC[C@]12C</smiles><smiles>[R][C@@](C)(C=C)CC[C@]1(C)C(C)=CC[C@]2(C)[C@@H](C)CCC[C@]12C</smiles>

13 $\begin{aligned} 14 \mathrm{R} & =(\mathrm{S}) \mathrm{CH}_{3} \\ 15 \mathrm{R} & =(\mathrm{R}) \mathrm{CH}_{3}\end{aligned}$

$16 \mathrm{R}=$ Ribofuranose 17 R = O(4'-O-(2-Methyl)butanoyl)-arabinopiranose<smiles>C[C@H]1CC[C@]2(C)C=CCC[C@H]2[C@@]1(CCO)CC/C(=C/CO)CO</smiles><smiles>[R][C@H]1C=C[C@]2(C)CC[C@H](C)[C@](CCc3ccoc3)(C(=O)O)[C@H]2C1</smiles>

Figure No. 3

\section{Secondary metabolites of some high altitude plants}

The species of Espeletiinae subtribe, as well as other several high-altitude species produce a significant amount of volatile mono- and sesquiterpenes (Table No. 1). Among them, there are some of taxonomic relevance for this subtribe. In some less-pubescent plants of páramo these compounds seem to be concentrated in the cuticular wax and glandular trichomes that use to cover all the adaxial surface of the leaves, giving it a sticky appearance (e.g. Minthostachys mollis; Rojas \& Usubillaga, 1995). Studies on the composition of essential oils in an altitudinal gradient as well as stages in the vegetative cycle in to species of the Andes Venezuelans (Coespeletia moritziana and Espeletia schultzii) show a change in the composition of these secondary metabolites with the altitude 
(Ibañez \& Usubillaga, 2006a; Ibañez \& Usubillaga, 2006b). The defensive character of these oils in Espeletiinae has not been systematically studied although the presence of high quantities of monoterpenes (Table No. 1), known as insecticides suggests, a possible potential defensive role.

Table No. 1

Composition of the essential oils of Andean plants selected

\begin{tabular}{|c|c|c|c|c|}
\hline Species & Elevation (m) & $\%(\mathrm{~m} / \mathrm{m})$ & Main components (\%) & References \\
\hline $\begin{array}{l}\text { Coespeletia } \\
\text { timotensis }\end{array}$ & 4000 & 0.45 & $\begin{array}{l}\beta \text {-phellandrene }(46), \alpha / \beta \text {-pinene } \\
(39), \text { kaur-16-ene }(0.9)\end{array}$ & Rojas et al., 1999 \\
\hline C. moritziana & 3750 & 0.58 & $\begin{array}{l}\alpha / \beta \text {-pinene }(56), \quad \beta \text {-phellandrene } \\
(18)\end{array}$ & Aparicio et al., 2002 \\
\hline C. spicala & 3850 & 0.02 & $\alpha / \beta$-pinene (57), $\alpha$-tujene (16) & Aparicio et al., 2002 \\
\hline C. thyrsiformis & 3000 & 0.2 & $\begin{array}{l}\alpha / \beta \text {-pinene }(30), \text { germacrene-D } \\
(15), \text { selinene }(6)\end{array}$ & Aparicio et al., 2002 \\
\hline $\begin{array}{l}\text { Espeletia } \\
\text { semiglobulata }\end{array}$ & 3800 & 0.2 & $\alpha$-tujene (73), $\alpha / \beta$-pinene (10), & Usubillaga et al., 1999 \\
\hline E. weddelli & 4080 & 0.18 & $\begin{array}{l}\text { p-cimene }(20), \alpha / \beta \text {-pinene }(19), \beta \text { - } \\
\text { phellandrene }(18),\end{array}$ & Khouri et al., 2000 \\
\hline E. nana & 3000 & 0.08 & $\alpha / \beta$-pinene (55), mircene (15) & Peña et al., 2012 \\
\hline E. batata & 4200 & 0.2 & $\begin{array}{l}\alpha / \beta \text {-pinene }(48), \quad \alpha \text {-tujene }(13), \\
\text { limonene (9) (-)-kaur-16-en-19-al } \\
(1.6)\end{array}$ & Usubillaga et al., 2001a \\
\hline E. grandiflora & 3328 & - & $\alpha$-pinene (69.7), $\beta$-pinene (3.4) & $\begin{array}{l}\text { Padilla-González et al., } \\
2016\end{array}$ \\
\hline E.killipi & 3717 & - & $\begin{array}{l}\alpha \text {-pinene (61.8), Sabinene (6.5), } \\
\beta \text {-pinene (4), }\end{array}$ & $\begin{array}{l}\text { Padilla-González et al., } \\
2016\end{array}$ \\
\hline $\begin{array}{l}\text { Espeletiopsis } \\
\text { angustifolia }\end{array}$ & 2870 & 0.18 & $\begin{array}{l}\alpha \text {-pinene }(30), \quad \beta \text {-caryophyllene } \\
(14), \alpha \text {-gurjunene }(9.9), \beta \text {-pinene } \\
(9.6),(-) \text {-kaur-16-en-19-al }(5.3)\end{array}$ & Meccia et al., 2007 \\
\hline $\begin{array}{l}\text { Rullopezia } \\
\text { marcesans }\end{array}$ & 3000 & 0.03 & $\begin{array}{l}\alpha / \beta \text {-pinene }(35), \text { germacrene-D } \\
(34),(-) \text {-kaur-16-en-19-al }(0.5)\end{array}$ & Aparicio et al., 2001 \\
\hline R. lindenil & 3100 & 0.04 & $\begin{array}{l}\alpha / \beta \text {-pinene }(35), \text { germacrene-D } \\
(34),(-) \text {-kaur-16-en-19-al }(2.5)\end{array}$ & Aparicio et al., 2001 \\
\hline R. atropurpurea & 3400 & 0.03 & $\begin{array}{l}\text { limonene (49) } \alpha / \beta \text {-pinene }(12), \\
\text { mircene (12), (-)-kaur-16-en-19-al } \\
(11)\end{array}$ & Aparicio et al., 2001 \\
\hline R. floccosa & 3800 & 0.08 & $\begin{array}{l}\alpha / \beta \text {-pinene }(31), \text { limonene }(24),(- \\
\text { )-kaur-16-en-19-al (4.4) }\end{array}$ & Aparicio et al., 2001 \\
\hline R. bracteosa & 3085 & 0,23 & $\begin{array}{l}\text { mircene (34.2), } \alpha / \beta \text {-pinene (32), } 7 \text { - } \\
\text { epi- } \alpha \text {-selinene }(9.1), \text { kaur-16-en- } \\
19 \text {-al (3.0) }\end{array}$ & Alarcón et al., 2015 \\
\hline $\begin{array}{l}\text { Libanothamus } \\
\text { occultus }\end{array}$ & 2800 & 0.11 & $\begin{array}{l}\alpha / \beta \text {-pinene }(44), \text { mircene }(17), \mathrm{p}- \\
\text { cimene }(11),(-) \text {-kaur-16-en-19-al } \\
(0.2)\end{array}$ & Usubillaga et al., 2001b \\
\hline L. nerifolia & 2800 & 0.13 & $\begin{array}{l}\text { sabinene (26), limonene (19), } \alpha- \\
\text { tujene }(18), \alpha \text {-phellandrene(11), } \\
\alpha / \beta \text {-pinene (6) }\end{array}$ & Usublllaga et al., 2001b \\
\hline L. humbertii & 3200 & 0.05 & $\begin{array}{l}\text { limonene (19), } \alpha \text {-tujene (18), } \alpha \text { - } \\
\text { phellandrene }(17), \alpha / \beta \text {-pinene } 15), \\
(-) \text {-kaur-16-en-19-al }(0.2)\end{array}$ & Usubillaga et al., 2001b \\
\hline L. lucidus & 3400 & 0.10 & $\begin{array}{l}\alpha \text {-tujene }(30), \alpha / \beta \text {-pinene }(28), \alpha- \\
\text { phellandrene }(10)(-) \text {-kaur-l6-en- }\end{array}$ & Usublllaga et al., 2001b \\
\hline
\end{tabular}




\begin{tabular}{|c|c|c|c|c|}
\hline \multirow[b]{2}{*}{ L. schideana } & \multirow[b]{2}{*}{3000} & \multirow[b]{2}{*}{0.26} & $19-\mathrm{al}(0.1)$ & \multirow[b]{2}{*}{ Rojas et al., 2004} \\
\hline & & & $\begin{array}{l}\text { ledol (29), D-3-carene (19), } \beta \text { - } \\
\text { phellandrene }(10)\end{array}$ & \\
\hline
\end{tabular}

There are different secondary metabolites capable of smoothing the strong incidence of UV lights in these habitats. Plants whose leaves are protected by woolly masses usually have low UV chemical filters. On the contrary, other plants accumulate significant quantities of these compounds. Some secondary metabolites such as stilbenes, flavonoids, lignans, tannins and others are able to absorb the UV radiation between 210 and 350 $\mathrm{nm}$. This optical characteristic could be a key factor in the development of these compounds as substances of adaptation to the UV radiation of the plant with the evolutionary time (Schnitzler et al., 1996, Bornman et al., 1997, Kolb et al., 2001; Padilla-Gonzalez et al., 2017). In fact, some tropical mountain species that grow on bare slopes accumulate unusual amounts of condensed phenolics and tannins in their aerial parts (Alonso-Amelot et al., 2007).

Kim et al., (2018) used proteomic tools to study the tolerance mechanism of Herpetospermum pedunculosum at high altitudes, 2800-3300 m.a.s.l. The results indicated that the chloroplast pathway, as well as signaling production, the ROS uptake path and the Calvin cycle pathway can collectively mediate adaptation to high altitudes in $H$. pedunculosum. In general, they showed that altitude affects some key stress and defense proteins to maintain the balance of ROS, and therefore, it could be considered that the increase in these proteins contribute to the greater tolerance of $H$. pedunculosum to a large altitude. High levels of some antioxidative enzymes and metabolites secondary antioxidants could be of significance for the response to high-altitude environments. Two compounds with structure of sesqui-norlignan, herpetone and dehydrodiconiferyl alcohol, were reported for this species, both aromatic compounds are able to absorb the UV radiation between 210 and $350 \mathrm{~nm}$ (Zhang et al., 2006). Blakiella bartsiifolia, a species of the Andean páramos at 4200 m.a.s.l. has a foliar surface are almost completely covered by glandular trichomes with accumulation of a colorless liquid at the edge of the vas. These drops may act as incidental sunlight refraction lens to modulate its impact on the underlaying parenchyma. Their cuticular waxes protecting the epidermis, represent to $9 \%$ of the leaf weight on a FW basis. Accumulation of cuticular exudate in such quantity has scarcely been described. Therefore, cuticular investment in $B$. bartsiifolia must be adaptive. The composition of this exudate includes a high content of flavones (21-22, see Figure No. 4) with absorbance in the UV-B zone that influences the vegetation at those elevations. Although the atmosphere at 3500-4200 m.a.s.l. filters off radiation below $280 \mathrm{~nm}$, the molecular structure of many flavonoids includes chromophores with important molar extinction coefficients above the cutoff wavelength, thus providing UV-B protection. (Calcagno-Pissarelli et al., 2010). In Arnica montana cv. ARBO was reported that the ratio of 3',4'dihydroxylated flavonoids to flavonoids without that substitution pattern, generate a positive correlation in the proportion of quercetin derivatives to kaempferol derivatives to the altitude of the growing site. The data revealed that the DPPH radical scavenging potential of flowering stems from plants grown at higher altitudes was significantly higher than that of lowland plants (Spitaler et al., 2008). It is known that quercetin derivatives are three to four times more potent radical scavenging, than kaempferol derivatives (Rice-Evans et al., 1996). PadillaGonzalez et al., (2017), based on a study with metabolomics approach showed that in species from Espeletia genus collected at heights more than 3000 m.a.s.l. from the páramos of Colombia and Venezuela, biosynthesized high quantities of the flavonoids (Figure 4). For example, species located in páramos of Boyacá (Colombia) at 3000-4200 m showed high quantities of the flavonoids 3-methoxy quercetin and hesperetin (23-24), whereas species from páramos of Cundinamarca at 3200-4100 m a.s.1. were characterized by high quantities of dimeric flavonoids such as 8,8'-methylene-bisquercetin (25). Lastly, the species located in the paramos of Venezuela at 3000-4500 $\mathrm{m}$ a.s.l. were characterized by the presence of high quantities of glycosylated flavonoids, such as quercetin-3-O-galactoside (26). The accumulation of flavonoid in high quantities in most of the species of Espeletia genus from the páramos of Venezuela and Colombia, suggest that the increase of UV-B filtration compounds may converge towards thermal protection against low temperatures and act on the cells that produce reactive oxygen species (ROS) (Chalker-Scott \& Scott, 2004; Spitaler et al., 2008). 
<smiles>COc1cc(-c2oc3cc(OC)c(OC)c(OC)c3c(=O)c2OC)ccc1O</smiles>

21<smiles>COc1cc(-c2oc3c(OC)c(O)cc(O)c3c(=O)c2OC)ccc1O</smiles>

23<smiles>COc1ccc(C2CC(=O)c3c(O)cc(O)cc3O2)cc1O</smiles><smiles>O=c1c(O)c(-c2ccc(O)c(O)c2)oc2c(Cc3c(O)cc(O)c4c(=O)c(O)c(-c5ccc(O)c(O)c5)oc34)c(O)cc(O)c12</smiles><smiles>O=C(O)[C@H]1O[C@H](Oc2c(-c3ccc(O)c(O)c3)oc3cc(O)cc(O)c3c2=O)[C@H](O)[C@@H](O)[C@H]1O</smiles><smiles>O=c1c(O[C@@H]2O[C@H](CO)[C@@H](O)[C@H](O)[C@H]2O)c(-c2ccc(O)c(O)c2)oc2cc(O)cc(O)c12</smiles>

28<smiles>O=c1c(O[C@@H]2O[C@H](CO)[C@@H](O)[C@H](O)[C@H]2O)c(-c2ccc(O)cc2)oc2cc(O)cc(Cl)c12</smiles>

29<smiles>COc1cc(-c2oc3cc(O)cc(O)c3c(=O)c2O[C@@H]2O[C@H](CO)[C@@H](O)[C@H](O)[C@H]2O)ccc1O</smiles>

30<smiles>Oc1cc(O)c2c(c1)O[C@H](c1ccc(O)c(O)c1)[C@H](O)C2c1c(O)cc(O)c2c1O[C@H](c1ccc(O)c(O)c1)[C@H](O)C2</smiles><smiles>Oc1cc(O)c2c(c1)O[C@H](c1ccc(O)c(O)c1)[C@H](O)C2</smiles><smiles>Oc1cc(O)c2c(c1)O[C@H](c1ccc(O)c(O)c1)[C@H](O)C2</smiles>

33<smiles>O=c1c(O[C@@H]2O[C@H](CO)[C@@H](O)[C@H](O)[C@H]2O)c(-c2ccc(O)c(O)c2)oc2cc(O)cc(O)c12</smiles>

34

Figure No. 4

Flavonoids reported for some plants of high mountains habitat

Andean species of Hypericum, located in the altitudinal range of 3000-5000 m.a.s.l., have been reported the presence of different types of aromatic compounds (Crockett et al., 2010). Tocci et al., (2018) based on presence or absence of 34 phenolic compounds, identified and quantified from seven of Andean Hypericum species ( $H$. cardonae; $H$. cuatrecasii; $H$. myricariifolium; $H$. humboldtianum; $H$. carinosum; $H$. laricifoliium and $H$. garciae, all native to the páramo ecosystem in Colombia), and using tools of chemical clustering, reported that these species were divided into two chemical groups, the results reflected an evolutionary relationship, especially as chemical profiles are often diverse or homoplastic, and thus, largely independent of phylogeny at the species level (e.g. Farag et al., 2013). Of the 34 compounds identified, 22 were flavonoids, quercetin-3-glucuronide (27), quercetin3-glucoside (28), kaempferol-3-glucoside (29), isorhamnetin-3-glucoside (30), procyanidin B2 (31), epicathechin (32) and catechin (33) compounds (Fig. 4) were reported in higher amounts. Others 
Hypericum species (H. irazuense; H. gnidioides and $H$. laricifolium) from Andean mountains, has been reported the presence of xanthones derivatives compounds (Crockett et al., 2010; Ramirez-Gonzalez et al., 2013). Several dimeric acylphloroglucinols derivatives (Figure No. 5), hyperbrasilol B (35), isohyperbrasilol B (36), uliginosin B (37), isouliginosin B (38), and uliginosin A (39), were identified in different Hypericum species ( $H$. andinum; $H$. laricifolium; $H$. brevistylum and $H$. silenoides) collected from Peruvian Andean páramos at 3100-3600 m.a.s.1. (Ccana-Ccapatinta et al., 2015) besides, these species are rich in flavonoids principally hyperoside (34) that has been found in high quantities (Ccana-Ccapatinta et al., 2014).

The different class of aromatic compounds reported for some Andean Hypericum species, could indicate an important role in ecological niche differentiation; an argument in line with the hypothesis that adaptive radiation potentially explains the high richness in the Andean paramos of Hypericum species (Nürk et al., 2013).

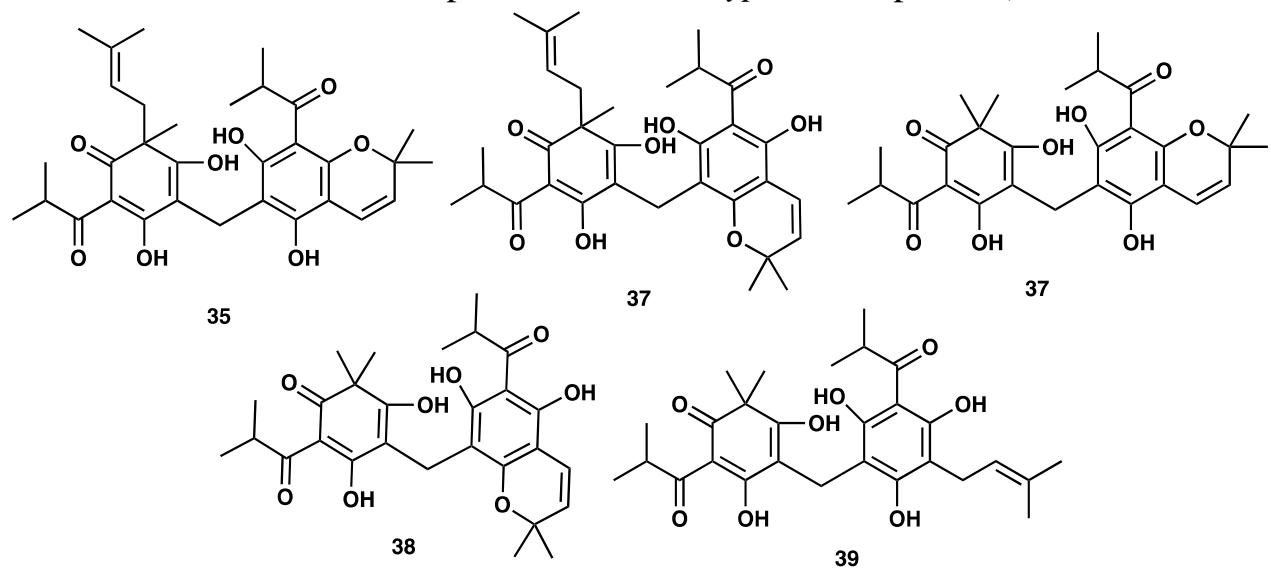

Figure No. 5

Some dimeric acylphloroglucinols reported for Hypericum Andean species

These aromatic natural compounds could be one of the strategies that Hypericum species use for their adaptation and acclimatization in these Andean ecosystems. No doubt, the secondary chemistry has an impact on acclimatization and adaptation, helping plants together with some physical defense strategies to withstand stressful conditions in high altitude ecosystems.

\section{Perspectives}

Considering that plants use different strategies, physical and chemical, to survive in environments with high levels of stress as those found in high mountain ecosystems. These fragile ecosystems extremes have been getting smaller by man as result of the implementation of agriculture. In this regard, by the benefit of these habitats is necessary the creating protected areas especially in tropical páramos that have been more affected by human activity. Exist are many questions to unravel in the complex relationships that occur in these ecosystems, the plants are a rich source of secondary metabolites, and it play a key role in the ecology of these environments. The plants localized at high altitude, most are endemic species very little studied, with a huge phytochemical potential that should be a source of inspiration for further research (pharmacological, agrochemical, ecological), which will result in a better understanding the different interactions that characterized in these high mountain environments.

The new investigations could be directed for example: What abiotic and biotic factors have been changing in the last decade as a result of climate change? How has this impacted and influenced the biosynthesis of secondary metabolites in plants? Has the phenotype and genotype been altered? Has secondary chemistry been altered as a strategy for plants to continue their survival in these high-altitude ecosystems? These are questions that still do not have a coherent answer and that should be considered, among others.

\section{ACKNOWLEDGMENTS}

The author is indebted to Dr. Miguel Alonso-Amelot (GQE-ULA) for fruitful discussions. D.R.H. acknowledges Fundação de Amparo à Pesquisa do Estado de São Paulo (FAPESP) for the Postdoctoral fellowship [grant \#2017/01188-4]. The author also 
acknowledges Coordenação de Aperfeiçoamento de Pessoal de Nível Superior (CAPES) and Conselho Nacional de Desenvolvimento Científico e Tecnológico (CNPq) for financial support.

\section{REFERENCES}

Alarcón L, Peña A, Velasco J, Baptista JG, Rojas L, Aparicio R, Usubillaga A. 2015. Chemical composition and antibacterial activity of the essential oil of Ruilopezia bracteosa. Nat Prod Commun 10: 655 - 656. https://doi.org/10.1177/1934578x1501000432

Alonso-Amelot ME, Oliveros-Bastidas A, CalcagnoPisarelli MP. 2004. Phenolics and condensed tannins in relation to altitude in neotropical Pteridium spp. A field study in the Venezuelan Andes. Biochem Syst Ecol 32: 969 - 981. https://doi.org/10.1016/j.bse.2004.03.005

Alonso-Amelot ME, Usubillaga A, Ávila Nuñez JL, Oliveros-Bastida A, Avendaño M. 2006. Effects of Minthostachys mollis essential oil and volátiles on seedlings of lettuce, tomato, cucumber and Biden pilosa. Allelopathy $\mathbf{J}$ 18: 267 - 276.

Alonso-Amelot ME, Oliveros-Bastidas A, CalcagnoPisarelli MP. 2007. Phenolics and condensed tannins of high altitude Pteridium arachnoideum in relation to sunlight exposure, elevation, and rain regime.

Biochem Syst Ecol 35: 1 - 10. Https://doi.org/10.1016/j.bse.2006.04.013

Alonso-Amelot ME. 2008. High altitude plants, chemistry of acclimation and Adaptation. Studies in Natural Product Chemistry 32: $883-982$. https://doi.org/10.1016/s1572-5995(08)80036-1

Amaro JM, Adrian M. 1982. Estudio Fitoquímico de la Flora Andina Venezolana I. Diterpenoides del Oxylobus glanduliferus (Sch.Bip.) Gray. Rev Latinoam Quim 13: 110 - 113.

Aparicio A, Romer M, Rojas LB, Khouri N, Usubillaga A. 2001. Composition of the essential oil of four species of Ruilopezia from the Venezuelan Andes. Flavour Fragr J 16: 172 - 174. https://doi.org/10.1002/ffj.973

Aparicio R, Romero M, Khouri N, Rojas LB, Usubillaga A. 2002. Volatile constituents from the leaves of three Coespeletia species from the Venezuelan Andes. J Essent Oil Res 14: 37 - 39. https://doi.org/10.1002/ffj.981

Bormnan JF, Reuber S, Cen Y-P, Weissenbock G. 1997. Ultraviolet radiation as a stress factor and the role of protective pigments. In: Lumsden PJ. (ed.), Plants and UV-B: Responses to environmental change. Cambridge University Press, Cambridge, UK.

https://doi.org/10.1017/cbo9780511752346.010

Calcagno-Pissarelli MP, Alonso-Amelot M, Mora R, Rodríguez D, Ávila-Nuñez JL. 2010. Foliar exudates of Blakiella bartsiifolia (S.F. Blake) Cuatrec. (Asteraceae, Astereae). A preliminary study of the chemical composition. Avances en Química 5: 161 166.

Callis-Duehl K, Vittoz P, Defossez E, Rasmann S. 2017. Community-level relaxation of plant defenses against herbivores at high elevation. Plant Ecol 218: 291 - 304. https://doi.org/10.1007/s11258-016-0688-4

Camas N, Radusiene J, Ivanauskas L, Jakstas V, Cirak C. 2014. Altitudinal changes in the content of bioactive substances in Hypericum orientale and Hypericum pallens. Acta Physiol Plant 36: 675 - 686. https://doi.org/10.1007/s11738-013-1446-z

Carey DB, Wink M. 1994. Elevational variation of quinolizidine alkaloid contents in a lupine (Lupinus argenteus) of the Rocky Mountains. J Chem Ecol 20: 849 - 857. https://doi.org/10.1007/bf02059582

Catalano S, Cioni PL, Martinozzi M, de Feo V, Morelli I. 1995. Chemical Investigation of Polylepis incana (Rosaceae). Biochem Syst Ecol 23: 105 - 107. https://doi.org/10.1016/0305-1978(95)93663-n

Ccana-Ccapatinta GV, Flores CS, Urrunaga Soria EJ, Choquenaira Pari G, Sánchez WG, Crockett SL, von Poser GL, del Jimenez C. 2014. Assessing the phytochemical profiles and antidepressant-like activity of four Peruvian Hypericum species using the murine forced swimming test. Phytochem Lett 10: $107-112$. https://doi.org/10.1016/j.phytol.2014.08.007

Ccana-Ccapatinta GV, Corrêa de Barros FM, Bridi H, von Poser GL. 2015. Dimeric acylphloroglucinols in Hypericum species from sections Brathys and Trigynobrathys. Phytochem Rev 14: 25 - 50. https://doi.org/10.1007/s11101-013-9332-2 
Chalker-Scott L, Scott J. 2004. Elevated UVB radiation induces cross protection to cold in leaves of Rhododendron under field conditions. Photochem Photobiol 79: 199 204.

https://doi.org/10.1562/00318655(2004)079<0199: eurict>2.0.co;2

Chinnusamy V, Schumaker K, Zhu JK. 2004. Molecular genetic perspectives on cross-talk and specificity in abiotic stress signaling in plants. J Exp Bot 55: 225 - 236. https://doi.org/10.1093/jxb/erh005

Crockett S, Eberhardt M, Kunert O, Schühly W. 2010. Hypericum species in the páramos of Central and South America: a special focus upon $H$. irazuense Kuntze ex N. Robson. Phytochem Rev 9: 255 - 269. https://doi.org/10.1007/s11101-009-9148-2

Descombes P, Marchon JN, Bilat J, Guisan A, Rasmann S, Pellissier L. 2016. Communitylevel plant palatability increases with elevation as insect herbivore abundance declines. J Ecol 105: 142 - 151. https://doi.org/10.1111/1365-2745.12664

Diaz A, Pefaur JE, Durant P. 1997. Ecology of the South American paramos with emphasis on the fauna of the Venezuelan páramoss. Wielgolaski FE (Ed.). Polar and alpine Tundra. Ecosystems of the World. Elsevier, Amsterdam, The Netherland.

Farag MA, Weigend M, Luebert F, Brokamp G, Wessjohann LA. 2013. Phytochemical, phylogenetic, and anti-inflammatory evaluation of 43 Urtica accessions (stinging nettle) based on UPLC-Q-TOF-MS metabolomic profiles. Phytochemistry 96: $170-183$. https://doi.org/10.1016/j.phytochem.2013.09.01 6

Gimenez E, Melendo M, Valle F, Gómez-Mercado F, Cano E. 2004. Endemic flora biodiversity in the south of the Iberian Peninsula: altitudinal distribution, life forms and dispersal modes. Biodivers Conserv 13: 2641 - 2660. https://doi.org/10.1007/s10531-004-2140-7

González-Reyes AX, Corronca JA, RodriguezArtigas SM. 2017. Changes of arthropod diversity across an altitudinal ecoregional zonation in North-western Argentina. Peer J 5: e4117.

https://doi.org/10.7717/peerj.4117
Gonzalo-Turpin H, Hazard L. 2009. Local adaptation occurs along altitudinal gradient despite the existence of gene flow in the alpine plant species Festuca eskia J Ecol 97: 742 - 751. https://doi.org/10.1111/j.13652745.2009.01509.x

Hamilton J, Zanger A, De Lucia E, Berenbaum M. 2001. The carbon-nutrient balance hypothesis: its rise and fall. Ecol Lett 4: 86 95.

https://doi.org/10.1046/j.14610248.2001.00192.x

Huang GT, Ma SL, Bai LP, Zhang L, Ma H, Jia P, Liu J, Zhonh M. 2012. Signal transduction during cold, salt, and drought stresses in plants. Mol Biol Rep 39: 969 - 987. https://doi.org/10.1007/s11033-011-0823-1

Ibañez J, Usubillaga A. 2006a. Analysis of the essential oil of two different altitudinal populations of Coespeletia moritziana (Sch. Bip.ex Wedd) Cuatrec. Flavour Fragr J 21: $760-763$. https://doi.org/10.1002/ffj.1655

Ibañez J, Usubillaga A. 2006b. The essential oil of Espeletia schultzii of different altitudinal populations. Flavour Fragr J 21: 286 - 289. https://doi.org/10.1002/ffj.1586

Ibrahim MH, Jaafar A, Rahmat A, Rahman Z. 2011. Effects of Nitrogen Fertilization on Synthesis of Primary and Secondary Metabolites in Three Varieties of Kacip Fatimah (Labisia Pumila Blume). Int J Mol Sci 12: 5238 5254. https://doi.org/10.3390/ijms12085238

Khouri N, Usubillaga A, Rojas LB, Galarraga F. 2000. The essential oil of Espeletia weddellii Sc. Bip. ex Wedd. Flav Fragr J 15: 236 265.

https://doi.org/10.1002/10991026(200007/08)15:4<263::aid-ffj907>3.0.co;2q

Kim HC, Peng M, Liu S, Wang Y, Li Z, Zhao S, Li S, Quan H, Luo Q, Meng F. 2018. Comparative proteomic analysis reveals the adaptation of Herpetospermum pedunculosum to an altitudinal gradient in the Tibetan Plateau. Biochem Syst Ecol 80: 1 10.

https://doi.org/10.1016/j.bse.2018.04.015

Kolb C, Kaser M, Kopeck J, Zotz G, Riederer M, Pufndel E. 2001. Effects of natural intensities of visible and ultraviolet radiation on 
epidermal ultraviolet screening and photosynthesis in grape leaves. Plant Physiol 127: 1 - 13.

https://doi.org/10.1104/pp.010373

Körner C. 1989. The nutritional status of plants from high altitudes. Oecologia 81: 379 - 391 . https://doi.org/10.1007/bf00377088

Körner C. 2003. Alpine plant life. Functional plant ecology of high mountain ecosystems. Springer, Berlin, Germany.

Körner C. 2007. The use of altitude in ecological research. Trends Ecol Evol 22: 569 - 574.

Lozano M, Flores YR, Almanza GR. 2017. High contents of oleanolic acid in highland Bolivian plants. Rev Bol Quim 34: 28 - 32.

Ma L, Suna X, Konga X, Galvane JV, Lia X, Yang S, Yanga Y, Yanga Y, Hu X. 2015. Physiological, biochemical and proteomics analysis reveals the adaptation strategies of the alpine plant Potentilla saundersiana at altitude gradient of the Northwestern Tibetan Plateau. J Proteomics 112: 63 - 82. https://doi.org/10.1016/j.jprot.2014.08.009

Meccia G, Rojas LB, Velasco J, Diaz T, Usubillaga A. 2007. Composition and antibacterial screening of the essential oils of leaves and roots of Espeletiopsis angustifolia Cuatrec. Nat Prod Commun 2: 1221 - 1224. https://doi.org/10.1177/1934578x0700201205

Neto CC, Vaisberg AJ, Zhou BN, Kingston D, Hammond GB. 2000. Cytotoxic Triterpene Acids from the Peruvian Medicinal Plant Polylepis racemose. Planta Med 66: 483 484.

https://doi.org/10.1055/s-2000-8583

Nürk NM, Scheriau C, Madriñán S. 2013. Explosive radiation in high Andean Hypericum-rates of diversification among New World lineages. Front Genet 4: 175.

https://doi.org/10.3389/fgene.2013.00175

Oleksyn J, Tjoelker MG, Reich PB. 1998. Adaptation to changing environment in Scots pine populations across a latitudinal gradient. Silva Fennica 32: 129 - 140.

https://doi.org/10.14214/sf.691

Oliveros-Bastidas AJ, Rodríguez-Hernández DC, Calcagno-Pissarelli $\quad$ MP. 2011. Estandarización de un bioensayo para la búsqueda de compuestos fitotóxicos en extractos vegetales. Ciencia 19: 187 - 202.

Padilla-González G, Aldana J, Da Costa F. 2016. Chemical characterization of two morphologically related Espeletia (Asteraceae) species and chemometric analysis based on essential oil components. Rev Bras Farmacogn 26: 694 - 700. https://doi.org/10.1016/j.bjp.2016.05.009

Padilla-González G, Diaz-Granados M, Da Costa F. 2017. Biogeography shaped the metabolome of the genus Espeletia: a phytochemical perspective on an Andean adaptive radiation. Sci Rep 7: 8835 . https://doi.org/10.1038/s41598-017-09431-7

Peña A, Rojas L, Aparicio R, Alarcón L, Baptista JG, Velasco J., Carmona J, Usubillaga A. 2012. Chemical composition and antibacterial activity of the essential oil of Espeletia nana. Nat Prod Commun 7: 661 - 662. https://doi.org/10.1177/1934578x1200700530

Premoli AC, Mathiasen P. 2011. Respuestas ecofisiológicas adaptativas y plásticas en ambientes secos de montaña: Nothofagus pumilio, el árbol que acaparó los Andes australes. Ecología Austral 21: 251 - 269.

Ramirez-Gonzalez I, Amaro-Luis JM, Bahsas A. 2013. Xanthones from aerial parts of Hypericum laricifoliium Juss. Nat Prod Commun 8: 1731 - 1732. https://doi.org/10.1177/1934578x1300801218

Rasmann S, Pellissier L, Defossez E, Jactel H, Kunstler G. 2014. Climate-driven change in plant-insect interactions along elevation gradients. Functional Ecology 28: 46 - 54. https://doi.org/10.1111/1365-2435.12135

Rice-Evans CA, Miller NJ, Paganga G. 1996. Structure-antioxidant activity relationships of flavonoids and phenolic acids. Free Rad Biol Med 20: 933 - 956. https://doi.org/10.1016/0891-5849(95)02227-9

Rodriguez-Hernandez D, Oliveros-Bastidas A, Alonso-Amelot M, Calcagno-Pissarelli MP. 2014. Diterpene Foliar Exudates of Blakiella bartsiifolia and Phytotoxicity of Clerodanes. Nat Prod Commun 9: 1407 - 1412. https://doi.org/10.1177/1934578x1400901003

Rodriguez-Hernandez D, Oliveros-Bastidas A, Alonso-Amelot M, Calcagno-Pissarelli MP. 2017. Two new labdane diterpenoids from the foliar exudates of Blakiella bartsiifolia, Phytochem Lett 20: 269 - 273. https://doi.org/10.1016/j.phytol.2017.05.001

Rojas J. 1998. Esparteina y lupanina: dos alcaloides quinolizidínicos de las especies Lupinus eremonomos y Lupinus meridanus. Rev Fac 
Farm (Mérida) 35: 21 - 27.

Rojas LB, Usubillaga A. 1995. Essential oil of Minthostachys mollis Grisebach from Venezuela. J Essent Oil Res 7: 211 - 213.

Rojas LB, Usubillaga A. 1998 Comparación de los componentes volátiles mayoritarios en diferentes épocas del año de la Coespeletia timotensis Cuatrec. Rev Fac Farm (Mérida) 36: $33-35$.

Rojas LB, Usubillaga A, Cegarra JA, Borregales E, Carrero S. 2004. Composición química y actividad antimicótica del aceite esencial de la Lepechinia schiedeana (Schlecht) Vatke. Rev Fac Farm (Mérida) 46: 27 - 30.

Rojas LB, Usubillaga A, Galarraga F. 1999. Essential oil of Coespeletia timotensis Cuatrec. Phytochemistry 52: 1483 - 1484. https://doi.org/10.1016/s0031-9422(99)00346-5

Schnitzler JP, Jungblut TP, Heller W, Kofferlein M, Hutzler P, Heinzmann Jr H. 1996. Tissue localization of UV-B screening pigments and of chalcone synthase mRNA in needles of Scots pine seedlings. New Phytol 132: 247 258.

https://doi.org/10.1111/j.1469-

8137.1996.tb01844.x

Shinozaki K, Yamaguchi-Shinozaki K. 2000. Molecular responses to dehydration and low temperature: differences and cross-talk between two stress signaling pathways. Curr Opin Plant Biol 3: 217 - 223.

https://doi.org/10.1016/s1369-5266(00)80068-0

Singh N, Gupta AP, Singh B, Kaul VK. 2005. Quantification of picroside-I and picroside-II in Picrorhiza kurrooa by HPTLC. J Liq Chromatogr Rel Technol 28: 1679 - 1691. https://doi.org/10.1081/jlc-200060439

Spitaler R, Winkler A, Lins I, Yanar S, Stuppner H, Zidorn C. 2008 Altitudinal variation of phenolic contents in flowering heads of Arnica montana cv. ARBO, a 3-year comparison. J Chem Ecol 34: 369 - 375. https://doi.org/10.1007/s10886-007-9407-x

Tocci N, Weil T, Perenzoni D, Narduzzi L, Madriñán S, Crockett S, Nürd NM, Cavalieri D, Mattivi F. 2018. Phenolic profile, chemical relationship and antifungal activity of Andean Hypericum species Industrial Crops \& Products 112: 32 - 37. https://doi.org/10.1016/j.indcrop.2017.10.030

Toro Gonzalez G, Rojas Villamil E, Arango Uribe G. 1997. Seneciose. Enfermedad veno-oclusiva del hígado (EVOH) en Colombia. 1964-1996 Identificacion, manejo y solución de un problema. Rev Acad Colomb Cienc 21: 35 56.

Usubillaga A, Khouri N, Rojas LB, Morillo M. 2001a. Essential oil of the leaves from Espeletia batata Cuatrec. J Essent Oil Res 13: 450 - 451. https://doi.org/10.1080/10412905.2001.9699725

Usubillaga A, Aparicio R, Romero M, Rojas LB, Khouri N. 2001b. Volatile constituents from the leaves of four Libanothamus species from the Venezuelan Andes. Flav Fragr J 16: 209 $-211$. https://doi.org/10.1002/ffj.981

Usubillaga A, Khouri N, Visbal T. 1999. Volatile constituents from the leaves of Espeletia semiglobulata Cuatrec. J Essent Oil Res 11: $757-758$. https://doi.org/10.1080/10412905.1999.9712013

Usubillaga A, Morales A. 1972. Kaurenic acids in Espeletia species. Phytochemistry 11: 18561857. https://doi.org/10.1016/0031-9422(72)85058-1

Usubillaga A, Romero M, Aparicio R. 2003. Kaurenic acids in Espeletiinae. Acta Hort 597: 129 - 130. https://doi.org/10.17660/actahortic.2003.597.17

Valero I. 2010. Estudio del potencial alelopático de Biocomunicadores de Oxylobus glanduliferus A. Gray. Dissertation, Universidad de Los Andes, Mérida-Venezuela.

Velez V, Cavelier J, Devia B. 1998. Ecological traits of the tropical treeline species Polylepis quadrijuga (Rosaceae) in the Andes of Colombia. J Trop Ecol 14: 771 - 787. https://doi.org/10.1017/s026646749800056x

Vetaas OR, Grytnes JA. 2002. Distribution of vascular plant species richness and endemic richness along the Himalayan elevation gradient in Nepal. Glob Ecol Biogeogr 11: $291-301$. https://doi.org/10.1046/j.1466822x.2002.00297.x

Zhang M, Dong XP, Deng Y, Wang H, Li XN, Song Q. 2006. A new sesqui-norlignan from Herpetospermum pedunculosum. Yao Xue Xue Bao 41: 659 - 661.

Zidorn C. 2010. Altitudinal variation of secondary metabolites in flowering heads of the Asteraceae: trends and causes. Phytochem Rev 9: 197 - 203. 
https://doi.org/10.1007/s11101-009-9143-7

Zlatev ZS, Lidon FCJ, Kaimakanova M. 2012. Plant physiological responses to UV-B radiation
Emir. J Food Agric 24: 481 - 501.

https://doi.org/10.9755/ejfa.v24i6.481501 